\title{
ESTIMATION OF ONDANSETRON HYDROCHLORIDE BY RP-HPLC
}

\author{
Dr. Juluri Krishna Dutta Tejaswi ${ }^{*} 1$ \\ ${ }^{1}$ Department of Pharmaceutical Analysis, C. R. R College of Pharmaceutical Sciences, \\ Eluru, West Godavari District (AP), India.
}

Article DOI: https://doi.org/10.36713/epra4412

\begin{abstract}
A RP-HPLC method was developed for the estimation of Ondansetron Hydrochloride in Bulk drug using high performance liquid chromatography. Ondansetron was a serotonin 5-HT receptor antagonist used mainly as an antiemetic drug to treat nausea and vomiting after cancer chemotherapy. The separation was achieved by Promosil C-18 (250 mm $\times 4.6 \mathrm{~mm} \times 10 \mu \mathrm{m}$ ) column because it allows higher separation and Acetonitrile: Methanol (50:50) as mobile phase with a flow rate of $1.2 \mathrm{ml} / \mathrm{min}$. The detection was carried out at $216 \mathrm{~nm}$. The retention time of drug was found 2.64 min. The developed method was validated. The proposed method shall prove equally effective to analyze Ondansetron Hydrochloride in the corresponding drug sample and may prove to be of great importance in pharmaceutical analysis.
\end{abstract}

KEYWORDS: Ondansetron, Acetonitrile, Antiemetic, Methanol.

\section{INTRODUCTION}

Ondansetron (1-2) was a serotonin $5-\mathrm{HT}_{3}$ receptor antagonist used mainly as an antiemetic drug to treat nausea and vomiting after cancer chemotherapy by reduces the activity of Vegas nerve which deactivates the vomiting centre in medulla oblongata and also blocks serotonin receptor in the chemoreceptor trigger zone. (3-4) It was chemically 4H-Carbazol-4-one, 1, 2, 3, 9-tetrahydro-9-methyl-3(2-methyl-1H-imidazol-1-yl)methyl-

monohydrochloride, $( \pm)$-,dihydrate. $( \pm)-2,3-\mathrm{Di}$ hydro- 9-methyl-3-(2-methylimidazol-1yl)methylcarbazol$4(1 \mathrm{H})$ onemonohydrochloride dihydrate. After through literature survey, the present method was developed as per ICH Guidelines (5-7). In the present work, an attempt was made to provide a newer, simple, accurate and low cost HPLC method based on solubility for the determination of Ondansetron Hydrochloride as an active pharmaceutical ingredient as shown in Fig. 1.

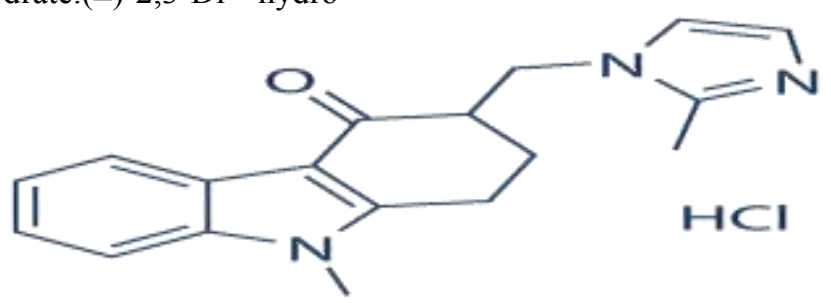

Fig. 1: Structure of Ondansetron Hydrochloride.

\section{MATERIAL AND INSTRUMENT}

HPLC method was developed and validated on Younglin HPLC model (Acme-9000. Double beam UV-Visible Spectrophotometer of companySystronic, Model (2101) with a $1 \mathrm{~cm}$ matching quartz cell was used. Ondansetron Hydrochloride was obtained from different companies as gift samples for research and was authenticated by Symed Lab. Ondansetron $\mathrm{HCl}$ Tablet (Zofron 4mg) of Cipla company was used. Methanol and 


\section{EPRA International Journal of Research and Development (IJRD) \\ Volume: 5 | Issue: 5 | May 2020 \\ - Peer Reviewed Journal}

Acetonitrile were of Merck Company. Potassium di hydrogen phosphate was of Rankem company.

\section{STANDARD SOLUTION PREPARATION}

Dissolved $9 \mathrm{mg}$ of Ondansetron Hydrochloride working standard into $100 \mathrm{ml}$ volumetric flask and volume was made up to the mark with mobile phase and dilute quantitatively with mobile phase to obtain a solution having concentration of about $90 \mu \mathrm{g} / \mathrm{ml}$ and Filtered through $0.45 \mu$.

\section{ABSORPTION MAXIMUM ( $\left.\lambda_{\text {Max }}\right)$}

Selection of Ondansetron Hydrochloride $(10 \mu \mathrm{g} / \mathrm{ml})$ was prepared in mobile phase. The max was determined on Shimadzu UV - visible spectrophotometer (Model UV - 1800 PC) in the range of 200-400nm and $\lambda_{\text {Max }}$ was found to be $216 \mathrm{~nm}$ as shown in Fig. 2.

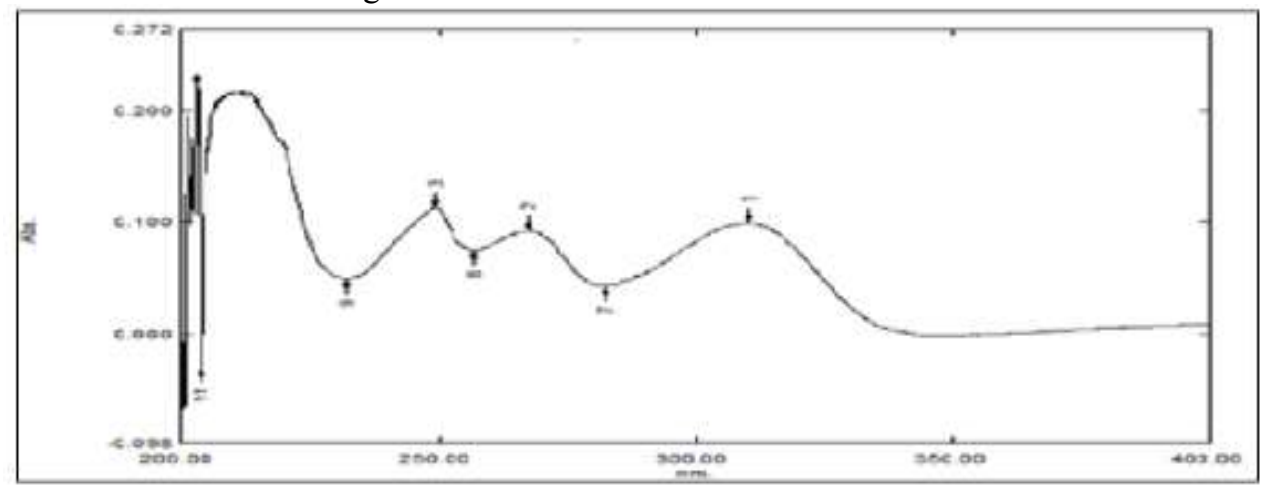

Fig. 2: UV - Absorption Spectra of Ondansetron Hydrochloride.

\section{METHOD OPTIMISATION}

Optimum condition of mobile phases was investigated in the development of an HPLC method suitable for analysis of Ondansetron hydrochloride in the bulk drug. The same solvent mixture was used for extraction of the drug from the formulation containing excipients as shown in Fig. 3 and Table 1.

Table 1: HPLC Chromatographic Conditions of Ondansetron Hydrochloride.

\begin{tabular}{|c|l|l|}
\hline S. No. & \multicolumn{1}{|c|}{ Parameters } & \multicolumn{1}{c|}{ Description } \\
\hline $\mathbf{1 .}$ & Instrument & $\begin{array}{l}\text { A HPLC instrument (Younglin series) with Model } \\
\text { Acme-9000. }\end{array}$ \\
\hline $\mathbf{2 .}$ & Column & Hypersil $\mathrm{C}_{18}$ column $(216 \mathrm{~mm}, 4.6 \mathrm{~mm}, 5 \mu \mathrm{m})$. \\
\hline $\mathbf{3 .}$ & Mobile Phase & Acetonitrile: Methanol $(50: 50)$. \\
\hline $\mathbf{4 .}$ & Flow Rate & $1.2 \mathrm{ml} / \mathrm{min}$. \\
\hline $\mathbf{5 .}$ & Detection wavelength & $216 \mathrm{~nm}$. \\
\hline $\mathbf{6 .}$ & Injection Volume & $10 \mu \mathrm{L}$. \\
\hline $\mathbf{7 .}$ & Auto Sampler Temperature & $5^{\circ} \mathrm{C}$. \\
\hline $\mathbf{8 .}$ & Run Time & $10 \mathrm{~min}$. \\
\hline
\end{tabular}

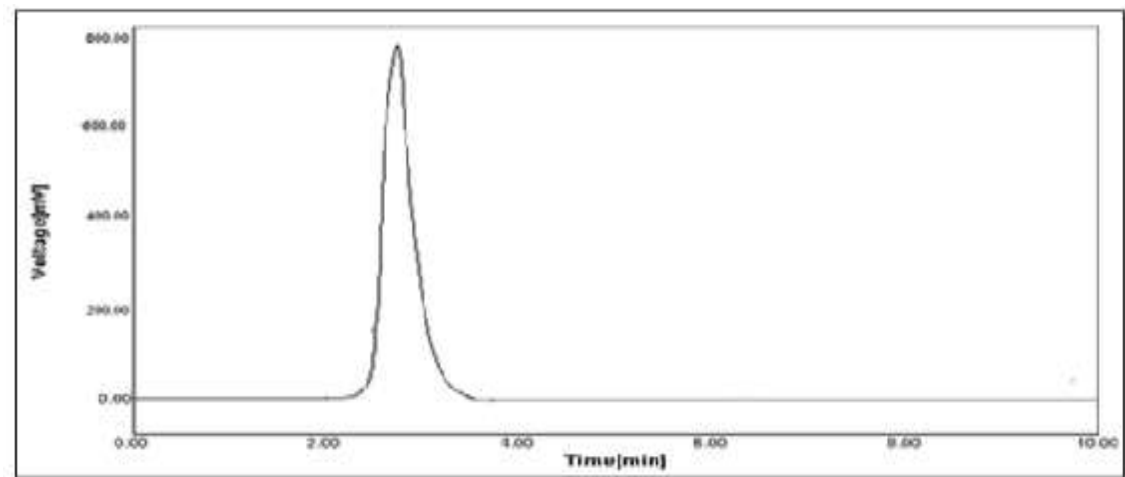

Fig. 3: Optimised Chromatogram of Ondansetron Hydrochloride.

(6020 EPRA IJRD | Journal DOI: https://doi.org/10.36713/epra2016 | www.eprajournals.com |30 | 


\section{EPRA International Journal of Research and Development (IJRD)

\section{ASSAY PROCEDURE}

Twenty tablets were weighed and average weight was determined. It was finely powdered and mixed thoroughly. Accurately weight tablet power equivalent to $9 \mathrm{mg}$ of Ondansetron hydrochloride and was transferred to dry stopped $100 \mathrm{ml}$ volumetric flask and made up with mobile phase and filtered through Whatmann filter paper. Further dilution was done with mobile phase to get concentration of 90 $\mu \mathrm{g} / \mathrm{ml}$. The chromatogram was recorded and response i. e peak areas of major peaks were measured as shown in Fig. 4 and Table 2.

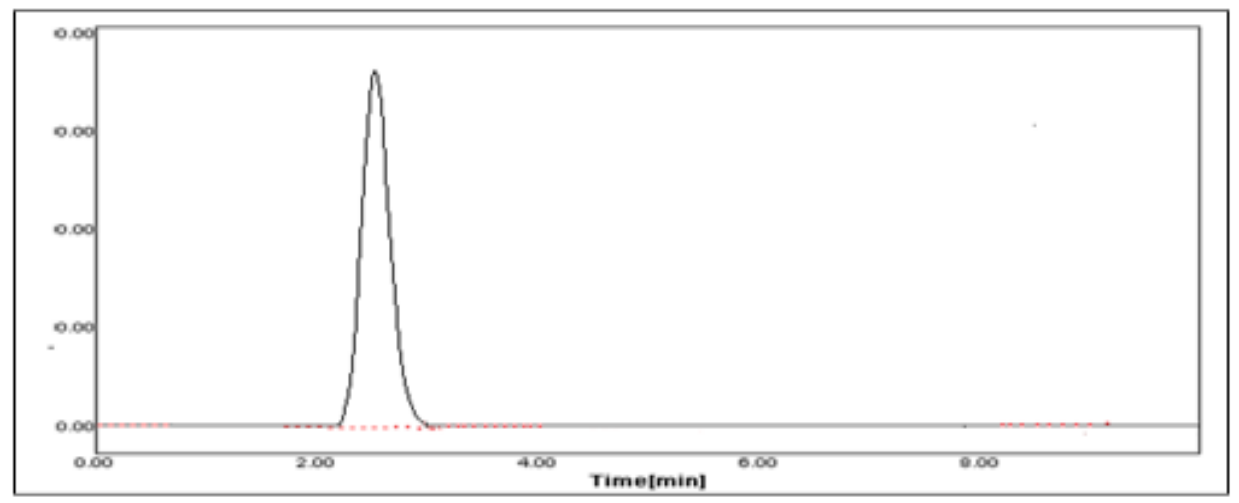

Fig. 4: Assay Chromatogram obtained by using marketed preparation.

Table 2: Analysis of Marketed Tablet Formulation

\begin{tabular}{|c|c|c|c|c|c|}
\hline S.No. & $\begin{array}{c}\text { Weight Taken } \\
\text { (mg) }\end{array}$ & $\begin{array}{c}\text { Standard } \\
\text { Peak Area }\end{array}$ & $\begin{array}{c}\text { Sample Peak } \\
\text { Area }\end{array}$ & $\begin{array}{c}\text { Amount } \\
\text { Estimated (mg) }\end{array}$ & $\begin{array}{c}\text { Labeled Claim } \\
\text { (\%) }\end{array}$ \\
\hline $\mathbf{1 .}$ & 495 & 48807 & 48897 & 4.21 & 100.18 \\
\hline $\mathbf{2 .}$ & 495 & 48807 & 48857 & 4.03 & 100.10 \\
\hline $\mathbf{3 .}$ & 495 & 48807 & 48604 & 3.98 & 99.58 \\
\hline $\mathbf{4 .}$ & 495 & 48807 & 48402 & 4.11 & 99.17 \\
\hline $\mathbf{5 .}$ & 495 & 48807 & 48381 & 4.10 & 99.13 \\
\hline \multicolumn{6}{|c|}{ Mean } \\
\hline S.D & 99.63 \\
\hline \multicolumn{6}{|c|}{ \%R.S.D } \\
\hline
\end{tabular}

\section{METHOD VALIDATION \\ Linearity}

Accurately weighed quantity of $10 \mathrm{mg}$ Ondansetron hydrochloride was transferred to $10 \mathrm{ml}$ volumetric flask and from the standard stock solution $1,2,3,4 \& 5 \mathrm{ml}$ was transferred to $100 \mathrm{ml}$ volumetric flask and the volume was made up to the mark with mobile phase to obtain concentration 10, 20, 30,40 \& $50 \mu \mathrm{g} / \mathrm{ml}$. Then dilution was injected and peak area was recorded. The graph concentration of drug Vs peak area depicted in Fig. 5 and Table 3. 


\section{EPRA International Journal of Research and Development (IJRD)}

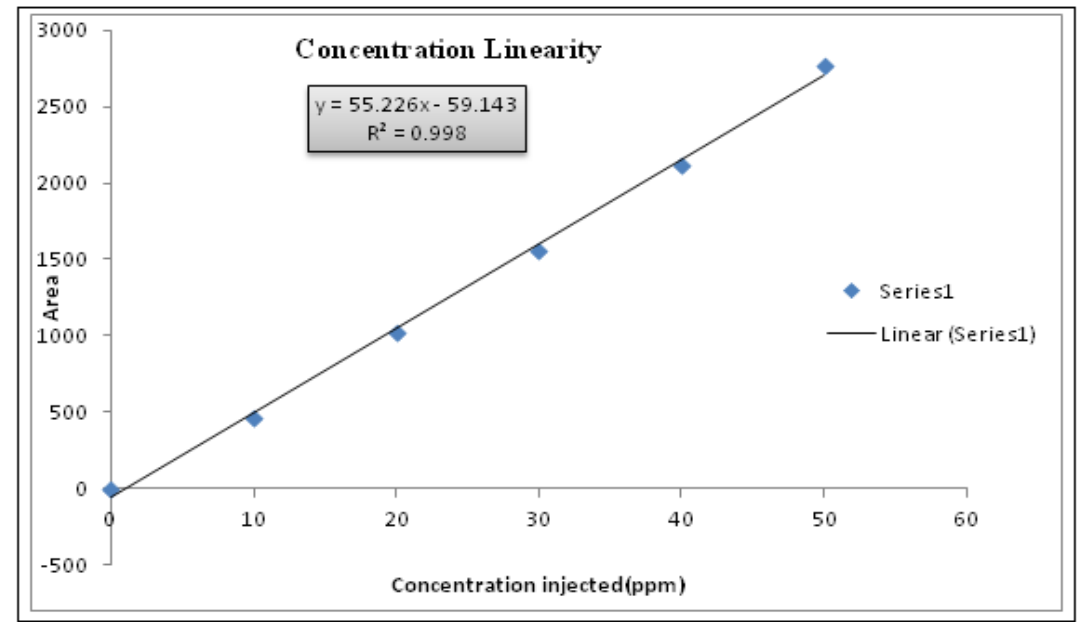

Fig. 5: Standard curve of Ondansetron Hydrochloride.

Table 3: Linearity Results of Ondansetron Hydrochloride.

\begin{tabular}{|c|c|c|}
\hline S.No. & Concentration $(\boldsymbol{\mu g} / \mathbf{m l})$ & Peak Area \\
\hline $\mathbf{1 .}$ & 10 & 465 \\
\hline $\mathbf{2 .}$ & 20 & 1018 \\
\hline $\mathbf{3 .}$ & 30 & 1561 \\
\hline $\mathbf{4 .}$ & 40 & 2122 \\
\hline $\mathbf{5 .}$ & 50 & 2763 \\
\hline
\end{tabular}

\section{System Suitability}

Accurately weighed quantity of $9 \mathrm{mg}$ of Ondansetron Hydrochloride was transferred to $100 \mathrm{ml}$ volumetric flask and dissolved in mobile phase and volume was made up to the mark with mobile phase to obtain solution of $90 \mu \mathrm{g} / \mathrm{ml}$. A $20 \mu \mathrm{l}$ standard solution was injected separately and their system suitability parameters were recorded. The tests were performed by collecting from five replicate injection of standard drug solution as shown in Fig. 6 and Table 4.

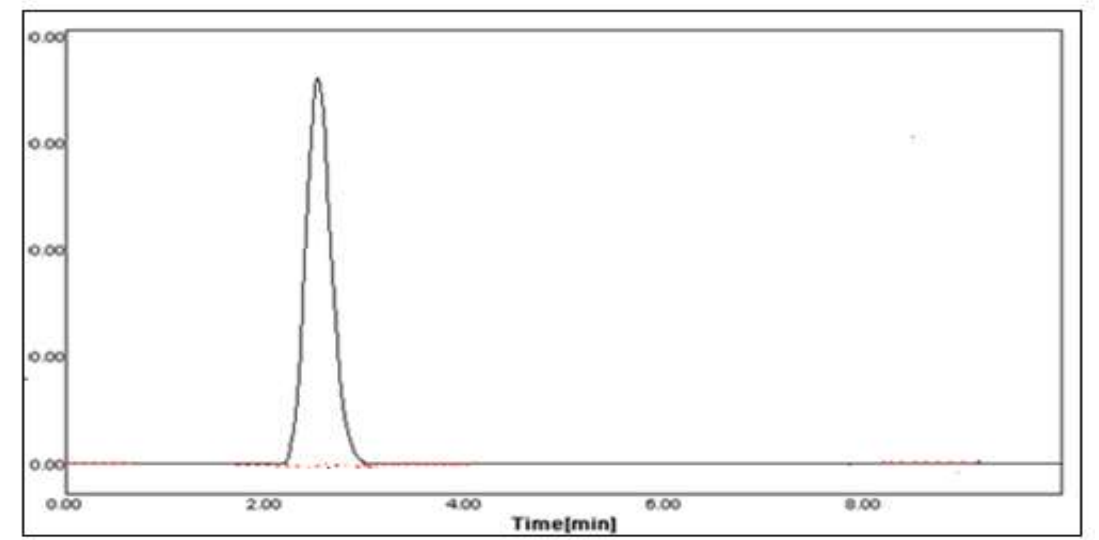

Fig. 6: System Suitability Chromatogram of Ondansetron Hydrochloride. 


\section{EPRA International Journal of Research and Development (IJRD)}

Table 4: System Suitability Results of Ondansetron Hydrochloride.

\begin{tabular}{|c|c|c|c|c|c|c|}
\hline S.No. & Rt (Min) & Peak area & $\begin{array}{c}\text { Tailing } \\
\text { Factor }\end{array}$ & Resolution & $\begin{array}{c}\text { Theoretical } \\
\text { Plates }\end{array}$ & $\begin{array}{c}\text { Asymmetry } \\
\text { Factor }\end{array}$ \\
\hline 1. & 2.64 & 48901 & 0.81 & 10.2 & 43264 & 1.25 \\
\hline $\mathbf{2 .}$ & 2.64 & 48904 & 0.81 & 10.2 & 43270 & 1.25 \\
\hline 3. & 2.62 & 49402 & 0.80 & 10.3 & 43560 & 1.29 \\
\hline 4. & 2.64 & 48504 & 0.80 & 10.3 & 43106 & 1.23 \\
\hline 5. & 2.63 & 47910 & 0.79 & 10.1 & 42897 & 1.20 \\
\hline MEAN & 2.634 & 48772.8 & 0.802 & 10.22 & 43219.4 & 1.234 \\
\hline S.D & 0.0089 & 629.77 & 0.008 & 0.083 & 243.6 & 0.02 \\
\hline \%RSD & 0.338 & 1.29 & 1.0 & 0.81 & 0.56 & 1.62 \\
\hline
\end{tabular}

\section{Accuracy}

Recovery of the method was evaluated by standard addition method in which appropriate portion of stock solutions of Ondansetron hydrochloride were spiked into blank placebo matrix to produce concentrations of 80,100 and $120 \%$ of theoretical concentration. The mean recovery of spiked samples obtained was in range of 99.96 to 100.36 reveals no interference of excipients. The total amount of drug estimated using formula given below and results of recovery studies are shown in Fig. 7 9 and Table 5.

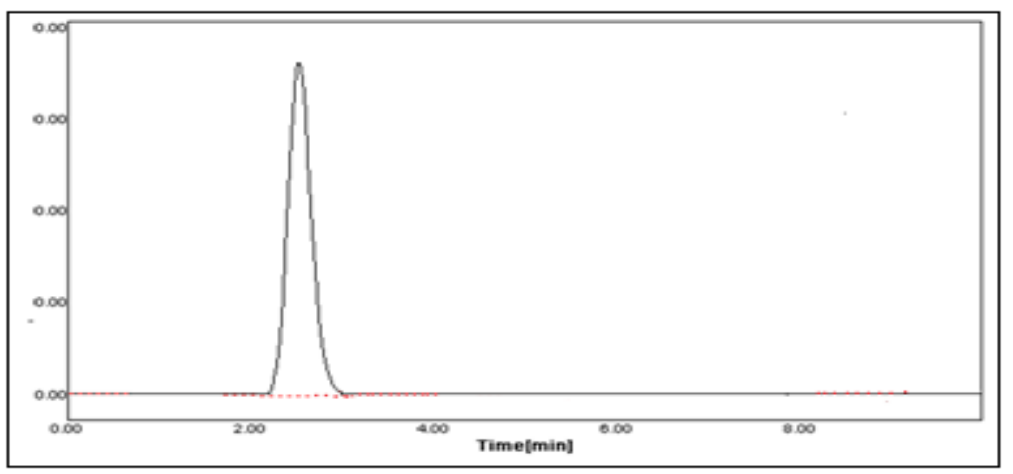

Fig. 7: Accuracy at $80 \%$ Chromatogram of Ondansetron Hydrochloride.

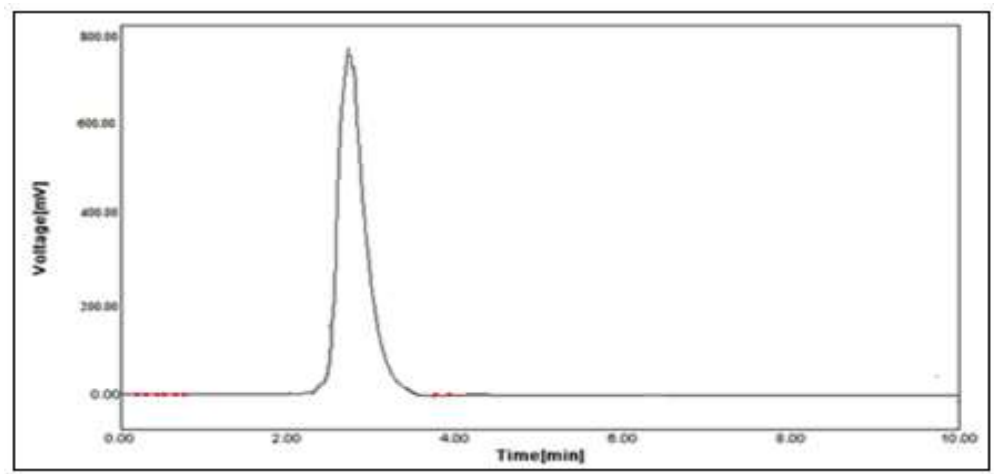

Fig. 8: Accuracy at $100 \%$ Chromatogram of Ondansetron Hydrochloride. 


\section{EPRA International Journal of Research and Development (IJRD)}

Volume: 5 | Issue: 5 | May 2020

- Peer Reviewed Journal

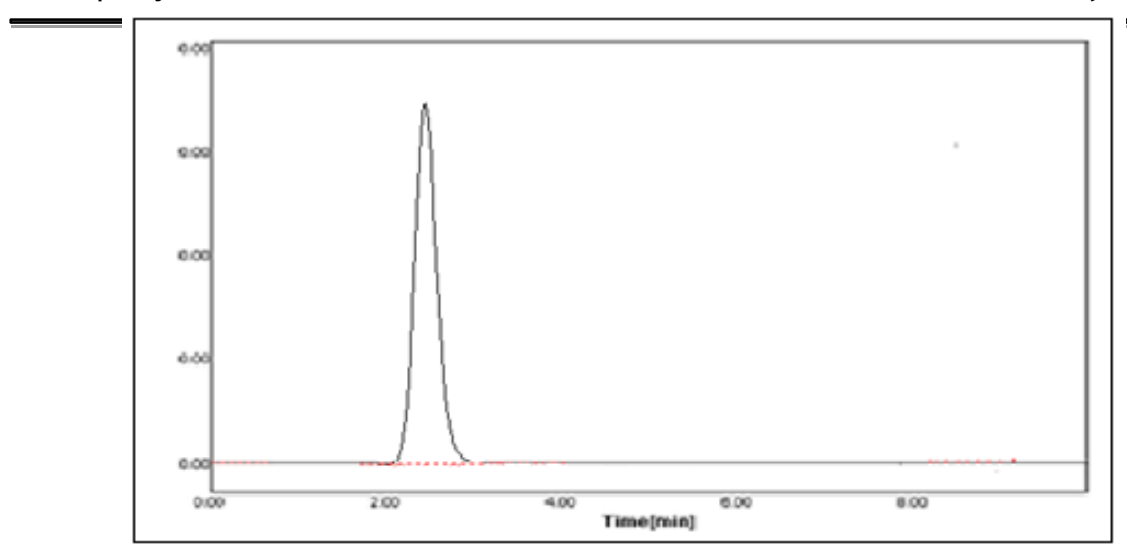

Fig. 9: Accuracy at $120 \%$ Chromatogram of Ondansetron Hydrochloride.

Table 5: Results of Accuracy studies of Ondansetron Hydrochloride

\begin{tabular}{|c|c|c|c|c|}
\hline $\begin{array}{c}\text { Amount } \\
\text { Added (\%) }\end{array}$ & $\begin{array}{l}\text { Total amount } \\
\text { Added (mg) }\end{array}$ & $\begin{array}{c}\text { Amount } \\
\text { Recovered (mg) }\end{array}$ & $\begin{array}{c}\text { \%Recovery } \\
\pm \text { SD }\end{array}$ & \%RSD \\
\hline \multirow{3}{*}{80} & 7.2 & 7.12 & \multirow{3}{*}{$99.96 \pm 0.30$} & \multirow{3}{*}{0.31} \\
\hline & 7.2 & 7.13 & & \\
\hline & 7.2 & 7.11 & & \\
\hline \multirow{3}{*}{100} & 8.0 & 7.81 & \multirow{3}{*}{$99.77 \pm 0.41$} & \multirow{3}{*}{0.40} \\
\hline & 8.0 & 7.80 & & \\
\hline & 8.0 & 7.82 & & \\
\hline \multirow{3}{*}{120} & 8.8 & 8.92 & \multirow{3}{*}{$100.36 \pm 0.52$} & \multirow{3}{*}{0.51} \\
\hline & 8.8 & 8.90 & & \\
\hline & 8.8 & 8.94 & & \\
\hline
\end{tabular}

SD: standard deviation, \% RSD: Relative standard deviation

\section{Limit of Detection and Limit of Quantitation}

LOD and LOQ were estimated from single to noise ratio using $3.3 \mathrm{\sigma} / \mathrm{s}$ and $10 \mathrm{\sigma} / \mathrm{s}$ respectively. LOD and LOQ were found to 1.7 and $5.26 \mu \mathrm{g} / \mathrm{ml}$.

\section{CONCLUSION}

The developed method was validated for various parameters and found to be reliable and accurate. The detection was carried out at $216 \mathrm{~nm}$. The retention time of drug was found $2.64 \mathrm{~min}$. The proposed method shall prove effective to analyze Ondansetron Hydrochloride in the corresponding drug sample.

\section{REFERENCES}

1. Pillai $S$ and Singhvi I. Spectrophotometric simultaneous estimation of ranitidine hydrochloride and Ondansetron hydrochloride from tablet formulation. Ind J Pharm Sci. 2007, 69 (4); Pg: 601-604.
2. Dedania Z, Dedania $R$, Karkhanis $V$, Sagar $G V$, Baldania M and Sheth N R. RP-HPLC Method for Simultaneous Estimation of Omeprazole and Ondansetron in Combined Dosage Forms. Asian J. Research Chem. 2009, 2(2); Pg: 108-111.

3. Raza A, Ijaz $A \quad S$ and Rasheed $U$. Spectrophotometric Determination of Ondansetron Hydrochloride in Pharmaceutical Bulk and Dosage Forms. J Chin Chem Soc. 2007, 54(1); Pg: 223-227.

4. Lobhe $G A$, Banerjee $S K$, Shirkhedkar $A$ and Surana $S$ J. Simultaneous Spectrophotometric Methods for Estimation of Ondansetron Hydrochloride and Omeprazole in Tablets. Int $J$ Res Pharm Chem. 2011, 1(3); Pg: 408-411.

5. ICH: Q2B, Analytical Validation - Methodology (November 1996), Pg No 24.

6. ICH: Q2A, Text on validation of analytical procedure (October 1994), Pg No 22.

7. ICH Q2 (R1), Validation of Analytical Procedures Text and Methodology November 2005, Pg No 23. 